\section{CarakaTani \\ Journal of Sustainable Agriculture \\ ISSN 2613-9456 (Print) 2599-2570 (Online)}

\title{
The Effects of Types of Manure and Mycorrhizal Applications on Sandy Soils on the Growth and Yield of Curly Red Chili (Capsicum annum L.)
}

\author{
Sukmana Siswandana Putra*, Eka Tarwaca Susila Putra and Jaka Widada \\ Department of Agronomy, Faculty of Agriculture, Universitas Gadjah Mada, Yogyakarta, Indonesia \\ *Corresponding author: sukmanasputra@gmail.com
}

\begin{abstract}
Market demand for chilies continues to increase, so efforts are needed to increase the productivity of the chili plants. One of the efforts is by intensifying production factors such as applying fertilizers on beach sand which contain low nutrients and organic matter so that manure input is needed and also utilizes soil microbial technology in the form of arbuscular mycorrhizal fungi which are relatively cheap economically and environmentally friendly. The purpose of this research was to study the effect of types of manure and mycorrhizal applications on the growth and yield of curly red chili. The research was arranged in a strip-plot Randomized Completely Block Design (RCBD) consisting of two factors with three replications. The first factor is the type of fertilizer (cow manure, chicken manure, guano fertilizer, quail manure and urea fertilizer) and the second factor is the application of mycorrhizae (with and without). This study concludes that quail manure increases plant height. The addition of chicken manure, guano fertilizer and quail manure multiplies the total fruit production. The application of mycorrhizae gives the same results on the growth and yield of chili.
\end{abstract}

Keywords: guano fertilizer; manure; mycorrhiza; nitrogen

Cite this as: Putra, S. S., Putra, E. T. S., \& Widada, J. (2020). The Effects of Types of Manure and Mycorrhizal Applications on Sandy Soils on the Growth and Yield of Curly Red Chili (Capsicum annum L.). Caraka Tani: Journal of Sustainable Agriculture, 35(2), 258-267. doi: http://dx.doi.org/10.20961/carakatani.v35i2.34971

\section{INTRODUCTION}

Chili is an agricultural commodity that has high economic value and is widely used by Indonesian people as a spice in cooking. According to Pusat Data dan Sistem Informasi Pertanian (2015), the total chili consumption was expected to increase in 2015-2019 to $2.34 \mathrm{~kg}$ per capita due to an increase in red chili consumption by an average of $1.67 \mathrm{~kg}$ per capita per year. Nowadays, the cultivation of curly red chili is carried out on sandy soils. The sandy soils in the Special Region of Yogyakarta range along $\pm 33 \mathrm{~km}$ across the southern part of Temon, Wates, Panjatan and Galur Sub-districts of Kulon Progo Regency, as well as Srambat, Wates and Kretek Sub-districts of Bantul Regency
(Anjarwati et al., 2013). Some weaknesses of cultivation in sandy soils include sandy texture, low organic matter and domination of macropores, which result in low water holding capacity. Zro et al. (2018) have stated that sandy soil has low organic matter (less than $1 \%$ ) so that the binding capacity of nutrients and cation exchange capacity are low. Besides, the carrying capacity of the quantity and activity of organisms is also low. Therefore, to support the success of cultivation in sandy soil, it is necessary to improve its physical, chemical and biological properties.

Poor soil quality is one of the causes of the low productivity of agricultural land in Indonesia. This relates to the properties of agricultural land such as seaside sand, which is low in nutrients. Inorganic fertilizer is a chemical that is

\footnotetext{
* Received for publication October 14, 2019

Accepted after corrections April 14, 2020
} 
deliberately given to meet the needs of plant nutrients. In general, farmers tend to use chemical fertilizers to accelerate the increase of nutrients in the cultivation of chili plants. Organic fertilizers contain macronutrients available for plants but slow-released compared to chemical fertilizers. It makes farmers prefer to use chemical fertilizers in the agricultural practice. However, if used continuously, chemical fertilizers can harm soils, such as hardened soil that results in stunted plant root growth (Chandini et al., 2019). Chemical fertilizers can increase soil productivity instantly but cause damage to soil structure (Setiawan et al., 2018). The negative impact of the use of chemical fertilizers on chili cultivation can be avoided by replacing them with organic fertilizers. The use of organic fertilizers is one of the ways to make the cultivation of chili plants into organic farming. Organic farming is defined as a practice of agricultural cultivation that relies on natural ingredients without using synthetic chemicals (Siddique et al., 2014).

The management of organic agriculture based on the principles of health, ecology, justice and protection. The principle of health in organic agriculture is that agricultural activities must pay attention to the preservation and improvement of the health of the soil, plants, animals, earth and humans as a single unit because all these components are interconnected and inseparable. One of the natural ingredients used in organic farming is manure. Manure as a source of organic material added to the soil will experience several phases by soil microorganisms to become humus (Elnasikh and Satti, 2017). Manure also acts as a source of energy and food for soil microbes to increase the activity of these microbes in the supply of plant nutrients. Organic fertilizers have the advantage of releasing nutrients slowly so that they have a residual effect in the soil and are beneficial for subsequent crops (Setiawan et al., 2018). Therefore, the use of organic fertilizer in the long term can support sustainable agriculture. According to Suryono et al. (2014), the utilization of livestock waste can support sustainable agriculture and is a service to the community.

Manure from all animal waste products that can be used to increase nutrients, as well as improve soil physical and biological properties. Nutrient content in manure is relatively low, but its role in the chemical properties of the soil far exceeds chemical fertilizers (Hartatik et al., 2015). Manure contains $60-70 \%$ organic matter
(Agustina et al., 2015). Organic matter plays an important role in the soil, which helps retain water to maintain water availability. Organic matter also helps to hold ions, which in turns increasing cation exchange capacity, providing nutrients, especially $\mathrm{N}, \mathrm{P}$ and $\mathrm{K}$, after the organic material has completely decomposed, helping the soil become more loose or crumbly to improve soil aeration and root system development. A good root system will spur the growth of microbes and other soil organisms in helping the process of decomposition of soil organic matter. Organic fertilizers and inorganic fertilizers give the same effects in the development and growth of eggplants (Solanum melongena L.) (Ali et al., 2019).

Yang et al. (2016) and Biratu et al. (2018) have stated that chicken manure is an important source of nutrients because it has higher nitrogen and phosphate contents than other manure. However, the research by Tiamiyu et al. (2012) has shown that cow manure produced higher yield and growth of okra. The result is higher than those with goat and chicken manure. According to the research of Setiawan et al. (2018), the application of organic fertilizer from quail manure produces higher yield compared to the chicken manure and without fertilization. Manure from quail quickly decomposes so easy to be directly absorbed by plants. Quail manure is also one type of fertilizers good enough to be used as fertilizer (Lubis et al., 2019). Guano fertilizer can increase the organic matter in the soil and improve nutrient content in lettuce plants (Ünal et al., 2018). The diversity of the results of those studies shows the importance of studying more about the use of manure in crop cultivation.

Amelioration of the sandy soil is done by adding manure and the use of soil microbial technology arbuscular mycorrhizal fungi (AMF). AMF is relatively inexpensive and environmentally friendly. These fungi have symbiotic relationship with roots and play an important role in plant growth, both ecologically and agronomically. These roles include increasing nutrient uptake such as N, P, K, Zn, Co, S and Mo from the soil, increasing plant tolerance to degraded land conditions, for example during drought, improving soil aggregation, increasing soil microbial growth, which is beneficial for host plant growth and as a protective plant from root pathogen infections (Smith and Smith, 2011). In addition to their interactions with plants, these 
arbuscular mycorrhizal fungi show symbiotic interactions in the soil environment. These interactions may be vital for sustainable agriculture because they mainly depend on biological processes rather than on agrochemicals to maintain plant growth and development as well as proper soil health on sandy soils ( $\mathrm{Pal}$ and Pandey, 2017). The purpose of this study was to identify the effect of manure and mycorrhizae on the growth and yield of curly red chili plants in sandy soils.

\section{MATERIALS AND METHOD}

The study was conducted in the Bugel sandy soils, Bugel Village, Panjatan Sub-district, Kulon Progo Regency. The land used as a research site is a lowland that is 7 meters above sea level and categorized as regosol soil. The properties of the soil are sand texture, loose structure, low organic matter content, $\mathrm{pH}$ 5.5-6.5 and grain size susceptible to erosion. This study was carried out from August 2018 to February 2019. The materials used during the study included F1 curly red chili seeds, several types of manure (chicken manure, cow manure, guano and quail manure), AMF, insecticide, fungicide, herbicide, nursery plastic, bamboo, rope, plastic, paper envelopes, nametag, nails, plastic mulch and other supporting materials. The tools used in this study were agricultural equipment, digital scales, leaf area meters, calipers, ovens, rulers, cameras and other supporting tools.

The research design used in this study was Strip Plot Design. The first factor was the application of mycorrhizae with two levels, namely without mycorrhizae and with mycorrhizal application with a dose of $10 \mathrm{~g}$ and applied during the nursery. The type mycorrhiza used was endomycorrhizal. The second factor was the type of fertilizer with 5 levels, namely without fertilizer (control), chicken manure with a dose of $16 \mathrm{~kg}$, cow manure with a dose of $20.6 \mathrm{~kg}$, guano fertilizer with a dose of $14.6 \mathrm{~kg}$, quail manure with a dose of $30 \mathrm{~kg}$ and urea fertilizer with a dose of $0.9 \mathrm{~kg}$ (Pusat Penelitian dan Pengembangan Hortikultura, 2019). One plot of land had an area of $6 \mathrm{~m} \mathrm{x} 1.5 \mathrm{~m}$. There were 12 treatment combinations with 3 replications. Fertilization was given by mixing with the soil before planting.

The variables examined in this research were root length and total root surface area observed at the age of 8 Week After Planting (WAP) plants.
The observation was carried out by separating the roots from the canopy, cutting and arranging the roots on a base and measuring them with an area meter. Leaf area was observed at the age of 8 WAP by placing the leaves on a pedestal and measuring them using a leaf area meter. Plant dry weight includes canopy dry weight (leaves, stems and generative organs) and root dry weight observed at the age of 8 WAP by putting the plants into an oven with a constant weight and weighing them using an analytical scale. Plant height was observed at the age of 8 WAP by measuring it from the base of the stem to the highest shoottip of the plant using a meter. The length and diameter of the fruit were monitored in each harvest period by using calipers. Crop productivity examined at the end of the harvest period through total chili harvest from each plot was weighed to determine the chili production per plot and then the results were converted to tons $\mathrm{ha}^{-1}$. Data analysis was performed using covariance analysis (ANCOVA) and then continued with the Duncan Multiple Range Tests (DMRT) with a level of 5\%.

\section{RESULTS AND DISCUSSION}

The root is the part of a plant organ for the nutrient uptake. The longer the root, the better the plant's ability to uptake nutrients because the range will be broader (Shahzad et al., 2014). Table 1 demonstrates that dealing with the parameters of the total root length, there was no interaction between manure and mycorrhizal application. The root length observed at $8 \mathrm{WAP}$ receiving treatments with cow, chicken, guano, quail and urea fertilizers, as well as without receiving any treatment (control) did not give any significant difference. The treatments with and without the addition of mycorrhizae did not either have any significant effect on the root length at 8 WAP. This is different from the research conducted by Zhang et al. (2016) that the application of mycorrhizae can increase total root length in black locust plants.

The roots will continue to form new, primary and lateral roots in their growth and development. The emergence of lateral roots is caused by the process of cell division and elongation in the meristem (Wu et al., 2016). Root surface area can indicate the effectiveness of root and nutrient uptake (Jozefaciuk and Lukowska, 2013). The wider the root surface area, the higher the root 
potential to uptake nutrients and water from the soil. The treatment of manure and mycorrhizal application did not indicate any interaction found on the root surface area aged 8 WAP (Table 1). The treatments with guano fertilizer and quail manure provide the best results, followed by chicken manure treatment. The treatments of cow manure and urea fertilizers and the treatment without any addition of fertilizers were not significantly different and had the lowest root surface area values. The addition of chicken manure presented a wider root surface than the addition of cow manure. The treatment with mycorrhizal and without mycorrhizal did not show any significant difference in the root area at the age of 8 WAP.

Table 1. Root length $(\mathrm{cm})$ and root surface area $\left(\mathrm{cm}^{2}\right)$ of curly red chili plants on various types of manure and mycorrhizae

\begin{tabular}{lrcc}
\hline \multicolumn{1}{c}{ Treatment } & Root length $(\mathrm{cm})$ & Root surface area $\left(\mathrm{cm}^{2}\right)$ & Leaf area $\left(\mathrm{cm}^{2}\right)$ \\
\hline Fertilizer & & & \\
Control & $59.59 \mathrm{a}$ & $250.44 \mathrm{c}$ & $861.23 \mathrm{c}$ \\
Cow manure & $98.71 \mathrm{a}$ & $285.76 \mathrm{c}$ & $1312.47 \mathrm{~b}$ \\
Chicken manure & $119.74 \mathrm{a}$ & $369.77 \mathrm{~b}$ & $1231.83 \mathrm{~b}$ \\
Guano & $91.18 \mathrm{a}$ & $724.56 \mathrm{a}$ & $1727.30 \mathrm{a}$ \\
Quail manure & $126.20 \mathrm{a}$ & $611.90 \mathrm{a}$ & $1515.52 \mathrm{ab}$ \\
$\quad$ Urea & $57.57 \mathrm{a}$ & $277.77 \mathrm{c}$ & $873.33 \mathrm{c}$ \\
Mycorrhizae & & & \\
Without application & $102.93 \mathrm{p}$ & $459.92 \mathrm{p}$ & $1274.99 \mathrm{p}$ \\
$\quad$ With application & $81.40 \mathrm{p}$ & $380.14 \mathrm{p}$ & $1232.22 \mathrm{p}$ \\
\hline Interaction & - & - & - \\
\hline Coefficient of diversity $(\%)$ & & & \\
Fertilizer & 75.25 & 58.89 & 22.21 \\
Mycorrhizae & 28.98 & 38.75 & 41.12 \\
\hline
\end{tabular}

Note: (-) does not show any interaction between factors of treatments; the number displayed is the adjusted mean value (adjusted mean); means followed by the same letters show no significant differences based on DMRT with a confidence level of $95 \%$

The leaves function as the main organ of photosynthesis to produce assimilates in plants. The wider the leaf, the easier it will be to intercept light. Based on Table 1, there is no interaction between manure treatments with the mycorrhizal application. The root area observed at 8 WAP obtaining treatment with guano fertilizer gave the highest yield but did not show any significant difference from treatment with quail manure. Treatment with quail manure was not significantly different from the treatments with cow and chicken manures. Meanwhile, both control treatment and urea treatment showed the lowest results. The increase in leaf area after treatments with manures is possible due to the availability of more nitrogen so plants uptake more nitrogen for broader leaf development (Ahmad et al., 2017). The effect of treatment with mycorrhizal application was not significantly different than that without mycorrhizal application on leaf area at the age of 8 WAP. Different results are shown in the study by Castillo et al. (2009) that mycorrhizae can increase leaf area due to the more effective nutrient uptake.

The dry weight of a plant is an accumulation of organic compounds synthesized by plants from inorganic compounds, especially water and carbon dioxide. Table 2 demonstrates that there was not any interaction found between the treatments of manure and mycorrhizae on leaf at the age of $8 \mathrm{WAP}$. The treatments of cow manure, chicken manure, guano manure, quail manure and urea fertilizer showed different results with the treatment without the addition of fertilizer. The use of manure gave a higher leaf dry weight than the control. Masito et al. (2014) have stated that the use of cow manure and chicken manure does not significantly demonstrate different results in soursop plants, but could increase total yields. The mycorrhizal application gave significantly higher results on the leaf dry weight compared to without mycorrhizal application. Based on the research of 
Muis et al. (2013), mycorrhizal inoculation significantly increases growth. In terms of the root, stem and total dry weight parameters, the results were not significantly different in all fertilizer treatments. Similarly, the dry weight parameters of roots stems and total were not significantly unlike on chili plants given mycorrhizae and without mycorrhizae.

Table 2. Plant dry weights (g) of curly red chili plants on various types of manure and mycorrhizae

\begin{tabular}{lcccc}
\hline \multicolumn{1}{c}{ Treatment } & $\begin{array}{c}\text { Leaves dry } \\
\text { weight }\end{array}$ & $\begin{array}{c}\text { Root dry } \\
\text { weight }\end{array}$ & $\begin{array}{c}\text { Stem dry } \\
\text { weight }\end{array}$ & $\begin{array}{c}\text { Total dry } \\
\text { weight }\end{array}$ \\
\hline Fertilizer & & & & \\
\hline Control & $14.81 \mathrm{~b}$ & $7.00 \mathrm{a}$ & $18.84 \mathrm{a}$ & $40.65 \mathrm{a}$ \\
Cow manure & $18.24 \mathrm{a}$ & $7.57 \mathrm{a}$ & $21.97 \mathrm{a}$ & $47.78 \mathrm{a}$ \\
$\quad$ Chicken manure & $18.25 \mathrm{a}$ & $7.96 \mathrm{a}$ & $24.60 \mathrm{a}$ & $50.81 \mathrm{a}$ \\
Guano & $19.99 \mathrm{a}$ & $8.82 \mathrm{a}$ & $28.51 \mathrm{a}$ & $57.31 \mathrm{a}$ \\
$\quad$ Quail manure & $21.23 \mathrm{a}$ & $9.53 \mathrm{a}$ & $25.79 \mathrm{a}$ & $56.55 \mathrm{a}$ \\
$\quad$ Urea & $17.29 \mathrm{a}$ & $7.76 \mathrm{a}$ & $22.71 \mathrm{a}$ & $47.66 \mathrm{a}$ \\
Mycorrhizae & & & & \\
$\quad$ Without application & $18.22 \mathrm{q}$ & $7.97 \mathrm{p}$ & $23.67 \mathrm{p}$ & $49.86 \mathrm{p}$ \\
$\quad$ With application & $18.38 \mathrm{p}$ & $8.21 \mathrm{p}$ & $23.81 \mathrm{p}$ & $50.39 \mathrm{p}$ \\
\hline Interaction & - & - & - & - \\
\hline Coefficient of diversity (\%) & & & & \\
Fertilizer & 18.00 & 14.71 & 18.15 & 16.55 \\
Mycorrhizae & 15.44 & 6.05 & 12.62 & 11.08 \\
\hline
\end{tabular}

Note: (-) does not show any interaction between factors of treatments; the number displayed is the adjusted mean value (adjusted mean); means followed by the same letters show no significant differences based on DMRT with a confidence level of $95 \%$

Plant height is an essential component of plant growth. Plant height can be measured easily using a ruler and is the main determinant of the ability of plants to compete in light (Moles et al., 2009). It can be seen in Table 3 that manure treatment and the mycorrhizal application did not show any interaction. At the height of the plant aged 8 WAP, guano fertilizer and quail manure gave the highest yield but the results were not significantly different from those of treatments with cow manure and chicken manure. Treatments with cow manure and chicken manure did not show significantly different effects from the treatment with urea fertilizer, whereas control gave the lowest yield but was not significantly different from the treatment with urea fertilizer. This is similar to the conclusion of the study by Fitrisiana et al. (2013) that the addition of chicken manure and cow manure increases plant height in sesame plants compared to controls. Beach sand has low colloidal properties and low organic matter so that nutrient binding capacity and cation exchange capacity are low.
Table 3. Plant height $(\mathrm{cm})$ of curly red chili on various types of manure and mycorrhizae

\begin{tabular}{lc}
\hline \multicolumn{1}{c}{ Treatment } & Plant height \\
\hline Fertilizer & \\
Control & $66.39 \mathrm{c}$ \\
Cow manure & $76.89 \mathrm{ab}$ \\
Chicken manure & $79.50 \mathrm{ab}$ \\
Guano & $84.56 \mathrm{a}$ \\
Quail manure & $84.89 \mathrm{a}$ \\
Urea & $72.45 \mathrm{bc}$ \\
Mycorrhizae & \\
Without application & $78.00 \mathrm{p}$ \\
With application & $76.89 \mathrm{pq}$ \\
\hline Interaction & - \\
\hline Coefficient of diversity $(\%)$ & \\
Fertilizer & 9.5 \\
Mycorrhizae & 10.6 \\
\hline
\end{tabular}

Note: (-) does not show any interaction between factors of treatments; the number displayed is the adjusted mean value (adjusted mean); means followed by the same letters show no significant differences based on DMRT with a confidence level of $95 \%$ 
This soil contains $\mathrm{P}$ that has not been available for plants and has low $\mathrm{N}$ and $\mathrm{K}$ nutrients. Therefore, it is necessary to add fertilizer to overcome the low nutrient availability to support optimal growth. In line with Khandaker et al. (2017), the addition of manure can increase plant growth. The addition of manure increases the availability of $\mathrm{N}, \mathrm{P}$ and $\mathrm{K}$ nutrients needed by plants during their growth. In the research of Ngkongolo et al. (2016), the results suggest that the addition of guano fertilizer gives the highest plant height in maize. Guano fertilizer has the property of releasing nutrients faster than other fertilizers so nutrient uptake is faster. The treatment with mycorrhizae and without mycorrhizae did not have a significant effect on plant height at the age of 8 WAP. According to Wicaksono et al. (2014), plant height after mycorrhizal application treatment is better than those without mycorrhizae. Mycorrhiza has an important role in plant growth and development.
The length and diameter of chili determined the quality of curly red chili yields. The optimal length and diameter will increase the selling power of the fruit. Curly red chili that longer and wider in diameter will increase the total chili yield. In the parameters of fruit diameter and fruit length, there was no interaction between manure treatment and mycorrhizal application. In the chili diameter parameter, cow manure, chicken manure, guano fertilizer, quail manure, urea fertilizer and control were not significantly different (Table 4). Furthermore, the treatment of mycorrhizae is not significantly different from the treatment without mycorrhizae. The control treatment was not significantly different from the treatment of cow manure, chicken manure and guano fertilizer, but it was significantly different from the treatment of quail manure and urea fertilizer. Mycorrhizal application is significantly different from without mycorrhizal application. The mycorrhizal treatment causes the curly red chili to be shorter.

Table 4. Diameter of fruit $(\mathrm{mm})$ and length $(\mathrm{cm})$ of curly red chili at various types of manure and mycorrhizae

\begin{tabular}{lcc}
\hline \multicolumn{1}{c}{ Treatment } & Diameter of curly red chili $(\mathrm{mm})$ & Length of curly red chili $(\mathrm{cm})$ \\
\hline Fertilizer & & \\
Control & $7.44 \mathrm{a}$ & $14.33 \mathrm{a}$ \\
Cow manure & $8.46 \mathrm{a}$ & $13.02 \mathrm{a}$ \\
Chicken manure & $7.26 \mathrm{a}$ & $13.40 \mathrm{a}$ \\
Guano & $7.72 \mathrm{a}$ & $13.13 \mathrm{a}$ \\
Quail manure & $7.28 \mathrm{a}$ & $7.94 \mathrm{c}$ \\
Urea & $7.40 \mathrm{a}$ & $9.06 \mathrm{~b}$ \\
Mycorrhizae & & \\
Without application & $7.46 \mathrm{p}$ & $14.26 \mathrm{p}$ \\
$\quad$ With application & $7.73 \mathrm{q}$ & $9.37 \mathrm{q}$ \\
\hline Interaction & - & - \\
Coefficient of diversity $(\%)$ & 11.10 & 3.99 \\
Fertilizer & 3.43 & 3.50 \\
Mycorrhizae & & \\
\hline
\end{tabular}

Note: (-) does not show any interaction between factors of treatments; the number displayed is the adjusted mean value (adjusted mean); means followed by the same letters show no significant differences based on DMRT with a confidence level of $95 \%$

Wu et al. (2016) and Onwu et al. (2018) have stated that the function of manure is to improve soil structure, supply nutrients, increase the ability of the soil to hold water and nutrients and increase the binding between particles. Besides, manure can improve the biological nature of the soil by accelerating the multiplication of microorganisms in the soil. Therefore, the addition of manure can improve the physical properties of the soil so that the plant can optimize the intake of nutrients for its growth and thus, increasing the quality of the chili plants.

Productivity is the result of the total production divided by land area. Table 5 presents that the addition of fertilizer could increase the total productivity of chili compared to the control, with the lowest productivity value. Whereas, both treatment with and without mycorrhizal 
application had no significant effect on productivity.

Table 5. Economic results of curly red chili on the addition of various types of fertilizer and mycorrhizae

\begin{tabular}{lc}
\hline \multicolumn{1}{c}{ Treatment } & Plant height \\
\hline Fertilizer & \\
Control & $7.24 \mathrm{~b}$ \\
Cow manure & $11.54 \mathrm{a}$ \\
Chicken manure & $12.97 \mathrm{a}$ \\
Guano & $13.14 \mathrm{a}$ \\
Quail manure & $12.35 \mathrm{a}$ \\
Urea & $13.44 \mathrm{a}$ \\
Mycorrhizae & \\
Without application & $11.49 \mathrm{p}$ \\
$\quad$ With application & $12.07 \mathrm{p}$ \\
\hline Interaction & - \\
\hline Coefficient of diversity (\%) & \\
Fertilizer & 26.47 \\
Mycorrhizae & 8.80 \\
\hline
\end{tabular}

Note: (-) does not show any interaction between factors of treatments; The number displayed is the adjusted mean value (adjusted mean). Means followed by the same letters show no significant differences based on DMRT with a confidence level of $95 \%$

The addition of manure could multiply crop productivity compared to the treatment without the addition of fertilizer. In line with the research by Adhikari et al. (2016), fertilizer application can increase the yields of paprika plants. This is because the addition of manure increases the microbial population and provides a source of energy for the microbes to remain active (Madhukumar et al., 2018). Therefore, plants can get nutrient intake in a form that is ready to be absorbed.

\section{CONCLUSIONS}

Guano and quail fertilizers performed the best effects on the growth of chili plants. However, the addition of all types of organic fertilizers gave a higher yield compared to controls. Organic fertilizers and urea produced equally good results. The application of mycorrhizae had the significantly different effects on the dry weight, diameter and length of curly red chili leaves. Thus, it can be concluded that organic fertilizer can replace the role of chemical fertilizers and mycorrhizae can be applied into the cultivation of curly red chili plants on sandy fields.

\section{REFERENCES}

Adhikari, P., Khanal, A., \& Subedi, R. (2016). Effect of different sources of organic manure on growth and yield of sweet pepper. Advances in Plants \& Agriculture Research, 3(5), 1-3. https://doi.org/10.15406/ apar.2016.03.00111

Agustina, Jumini, \& Nurhayati. (2015). Pengaruh jenis bahan organik terhadap pertumbuhan dan hasil dua varietas tomat (Lycopersicum esculentum Mill L.). Jurnal Floratek, 10(1), 46-53. Retrieved from http://jurnal.unsyiah. ac.id/floratek/article/view/2335

Ahmad, T., Shah, S. T., Ullah, F., Ghafoor, F., \& Anwar, U. (2017). Effect of Organic fertilizers on growth and yield of coriander. International Journal of Agricultural and Environmental Research, 3(1), 116-120. Retrieved from https://www.researchgate.net/publication/321 051277_EFFECT_OF_ORGANIC_FERTILI ZERS_ON_GROWTH_AND_YIELD_OF_C ORIANDER

Ali, M. A., Gençoğlan, C., \& Gençoğlan, S. (2019). The effects of organic and inorganic fertilizer applications on yield and plant vegetative growth of eggplant (Solanum melongena L.). International Journal of Plant \& Soil Science, 29(1), 1-9. https://doi.org/ 10.9734/ijpss/2019/v29i130132

Anjarwati, A., Istiyanti, E., \& Hasanah, U. (2013). Efisiensi penggunaan faktor produksi pada usahatani cabai merah (Capsicum spp.) di lahan pasir pantai Kecamatan Temon Kabupaten Kulon Progo. Surya Agritama, 2(1), 11-20. https://doi.org/10.24961/j.tek.ind. pert.2018.28.1.61

Biratu, G. K., Elias, E., Ntawuruhunga, P., \& Nhamo, N. (2018). Effect of chicken manure application on cassava biomass and root yields in two agro-ecologies of Zambia. Agriculture (Switzerland), 8(4), 1-15. https://doi.org/ 10.3390/agriculture8040045

Castillo R, C., Sotomayor S, L., Ortiz O, C., Leonelli C, G., Borie B, F., \& Rubio H, R. (2009). Effect of arbuscular mycorrhizal 
fungi on an ecological crop of chili peppers (Capsicum annuum L.). Chilean Journal of Agricultural Research, 69(1), 79-87. https:// doi.org/10.4067/s0718-58392009000100010

Chandini, Kumar, R., Kumar, R., \& Prakash, O. (2019). The impact of chemical fertilizers on our environment and ecosystem. Chapter: 5. Edition: $2^{\text {nd }}$ In book: Research Trends in Environmental Sciences, pp. 69-86). Retrieved from https://www.researchgate.net/ publication/331132826_The_Impact_of_Che mical_Fertilizers_on_our_Environment_and_ Ecosystem

Elnasikh, M., \& Satti, A. A. (2017). Potentiality of organic manures in supporting sustainable agriculture in Sudan. Environment and Natural Resources International, 2(1), 01-26. Retrieved from https://www.researchgate.net/ publication/329522648_Potentiality_of_Orga nic_Manures_in_Supporting_Sustainable_Ag riculture_in_Sudan

Fitrisiana, N., Taryono, \& Tohari. (2013). Pengaruh macam pupuk kandang terhadap pertumbuhan dan hasil wijen hitam dan wijen putih (Sesamum indicum L.). Vegetalika, 2(3), 45-53. Retrieved from https://jurnal.ugm. ac.id/jbp/article/view/3997

Hartatik, W., Husnain, \& Widowati, L. R. (2015). Peranan pupuk organik dalam peningkatan produktivitas tanah dan tanaman. Jurnal Sumberdaya Lahan, 9(2), 107-120 Retrieved from http://ejurnal.litbang.pertanian.go.id/ind ex.php/jsl/article/view/6600

Jozefaciuk, G., \& Lukowska, M. (2013). New Method for measurement of plant roots specific surface. American Journal of Plant Sciences, 4(5), 1088-1094. https://doi.org/ 10.4236/ajps.2013.45135

Khandaker, M. M., Rohani, F., Dalorima, T., \& Mat, N. (2017). Effects of different organic fertilizers on growth, yield and quality of Capsicum annuum L. var. kulai (Red chilli Kulai). Biosciences, Biotechnology Research Asia, 14(1), 185-192. https://doi.org/10.13005 /bbra/2434

Lubis, N., Refnizuida, R., \& R, H. I. F. (2019). Pengaruh pemberian pupuk organik daun kelor dan pupuk kotoran puyuh terhadap pertumbuhan dan produksi tanaman kacang panjang (Vigna cylindrica L). Talenta Conference Series: Science and Technology (ST), 2(1), 108-117. https://doi.org/10.32734/ st.v2i1.327

Madhukumar, V., Seenappa, C., Lalitha, B. S., Sharanappa \& Sanjay, M. T. (2018). Effect of organic farming practices on productivity, quality and economics of chilli hybrids in Central Dry Zone of Karnataka, India. International Journal of Current Microbiology and Applied Sciences, 7(2), 2877-2885. https: //doi.org/10.20546/ijcmas.2018.702.351

Masito, G. A. T., Respatie, D. W., \& Rogomulyo, R. (2014). Pengaruh lima macam pupuk organik terhadap pertumbuhan dan kandungan senyawa aktif daun sirsak (Annona muricata L.). Vegetalika, 3(3), 97-105. Retrieved from https://jurnal.ugm.ac.id/jbp/article/view 15417

Moles, A. T., Warton, D. I., Warman, L., Swenson, N. G., Laffan, S. W., Zanne, A. E., Pitman, A., Hemmings, F. A., \& Leishman, M. R. (2009). Global patterns in plant height. Journal of Ecology, 923-932. https://doi.org/ 10.1111/j.1365-2745.2009.01526.x

Muis, A., Indradewa, D., \& Widada, J. (2013). Pengaruh inokulasi mikoriza arbuskula terhadap pertumbuhan dan hasil kedelai (Glycine $\max$ (L.) Merrill) pada berbagai interval penyiraman. Vegetalika, 2(2), 7-20. Retrieved from https://jurnal.ugm.ac.id/jbp/ article/view/2411

Ngkongolo, M., Lumpungu, K., Kizungu, V., Kalambaie, M., Tshimbombo, J., \& Mukendi, K. (2016). Comparative effects of organic manure (Tithonia diversifolia and Bat-Guano) on the crop yield of corn (in monoculture and in association with cowpea) in Ngandajika Region in Central Democratic Republic of Congo. International Journal of Development Research, 06(01), 6410-6416. Retrieved from https://www.journalijdr.com/comparative-effe cts-organic-manure-tithonia-diversifolia-andbat-guano-crop-yield-corn-monoculture

Onwu, A., Osujieke, N., Gani, A., \& Ali, A. (2018). Influence of organic fertilizer $\left(\right.$ Nomau ${ }^{\circledR)}$ on Soil, leaf nutrient content, growth and yield of physic nut (Jatropha curcas) in Makurdi, North Central, Nigeria. Asian Journal of Soil Science and Plant 
Nutrition, 3(2), 1-11. https://doi.org/10.9734/ ajsspn/2018/42090

Pal, A., \& Pandey, S. (2017). Role of arbuscular mychrorrizal fungi on plant growth and reclamation of barren soil with wheat (Triticum aestivum L Crop.). International Journal of Soil Science, 12(1), 25-31. http:// dx.doi.org/10.3923/ijss.2017.25.31

Pusat Data dan Sistem Informasi Pertanian. (2015). Outlook cabai. Jakarta: Sekretariat Jenderal Kementerian Pertanian. Retrieved from http://epublikasi.setjen.pertanian.go.id/ arsip-outlook/76-outlook-hortikultura/355-out look-cabai-2015

Pusat Penelitian dan Pengembangan Hortikultura. (2019). Budidaya cabai. Jakarta: Balai Penelitian dan Pengembangan Pertanian. Kementerian Pertanian. Retrieced from https:// docplayer.info/69291317-Budidaya-cabai-pus at-penelitian-dan-pengembangan-hortikultura. html

Setiawan, M. A., Efendi, E., \& Mawarni, R. (2018). Effect of organic fertilizer and NPK fertilizer application on growth and yield of mungbean (Vigna radiata L.). Bernas Agriculture Research Journal, 14(3), 133144. Retrieved from http://jurnal.una.ac.id/ index.php/jb/article/view/379

Shahzad, H., Ullah, S., Iqbal, M., Javed, A., Jehan, S., Hussain, S., \& Siddiqui, A. R. (2014). Effect of various farm manure levels on root proliferation and maize growth under different soil textures. International Journal of Modern Agriculture, 3(4), 106-115. Retrieved from http://modern-journal.com/pdf2014/Dec 2014/1Rev1\%20Effect\%20of\%20various $\% 20$ farm\%20manure\%20levels.pdf

Siddique, S., Hamid, M., Tariq, A., \& Kazi, A. G. (2014). Organic Farming: The Return to Nature. In: Ahmad, P., Wani, M., Azooz, M., \& Phan Tran, L. S. (eds) Improvement of crops in the era of climatic changes. Springer, New York, NY. https://doi.org/10.1007/978-1-4614 -8824-8_10

Smith, S. E., \& Smith, F. A. (2011). Roles of Arbuscular mycorrhizas in plant nutrition and growth: New paradigms from cellular to ecosystem scales. Annual Review of Plant
Biology, 62(1), 227-250. https://doi.org/ 10.1146/annurev-arplant-042110-103846

Suryono, Dewi, W. S., \& Sumarno (2014). Pemanfaatan limbah peternakan dalam konsep pertanian terpadu guna mewujudkan pertanian yang berkelanjutan. Caraka Tani: Journal of Sustainable Agriculture, 29(2), 96100. https://doi.org/10.20961/carakatani.v29i 2.13378

Tiamiyu, R. A., Ahmed, H. G., \& Muhammad, A. S. (2012). Effect of sources of organic manure on growth and yields of okra (Abelmoschus esculentus L.) in Sokoto, Nigeria. Nigerian Journal of Basic and Applied Sciences, 20(3), 213-216. Retrieved from https://www.ajol.info/index.php/njbas/ article/view/85346

Ünal, M., Can, O., Can, B. A., \& Poyraz, K. (2018). The effect of bat guano applied to the soil in different forms and doses on some plant nutrient contents. Communications in Soil Science and Plant Analysis, 49(6), 708716. https://doi.org/10.1080/00103624.2018.1 434540

Wicaksono, M. I., Rahayu, M., \& Samanhudi. (2014). Pengaruh pemberian mikoriza dan pupuk organik terhadap pertumbuhan bawang putih. Caraka Tani: Journal of Sustainable Agriculture, 29(1), 35-44. https://doi.org/ 10.20961/carakatani.v29i1.13310

Wu, Q., Pagès, L., \& Wu, J. (2016). Relationships between root diameter, root length and root branching along lateral roots in adult, fieldgrown maize. Annals of Botany, 117(3), 379390. https://doi.org/10.1093/aob/mcv185

Yang, Q., Zhang, H., Guo, Y., \& Tian, T. (2016). Influence of chicken manure fertilization on antibiotic-resistant bacteria in soil and the endophytic bacteria of pakchoi. International Journal of Environmental Research and Public Health, 13(7), 662. https://doi.org/ 10.3390/ijerph13070662

Zhang, H., Liu, Z., Chen, H., \& Tang, M. (2016). Symbiosis of arbuscular mycorrhizal fungi and Robinia pseudoacacia L. improves root tensile strength and soil aggregate stability. PLoS ONE, 11(4), 5-9. https://doi.org/10.1371/ journal.pone. 0153378 
Zro, F. G. B., Guei, A. M., Nangah, Y. K., YaoKouame, A. (2018). Impacts of household waste compost formed in public garbage dump on the organo-mineral status and productivity of a sandy soil. International Journal of
Engineering and Applied Sciences, 5(2), 1-5. Retrieved from https://www.ijeas.org/impactsof-household-waste-compost-formed-in-publi c-garbage-dump-on-the-organo-mineral-status -and-productivity-of-a-sandy-soil 